\title{
ENGLISH WRITING NEEDS FOR ACADEMIC PURPOSES IN FORMAL HIGHER EDUCATION
}

\author{
Audi Yundayani, M.Pd. \\ Lecturer of STKIP Kusuma Negara Jakarta \\ audi.yundayani@gmail.com
}

\begin{abstract}
The study aimed to get the understanding about the learners' needs of English writing skill for academic purposes in formal higher education. As a part of English for Specific Purposes (ESP), English for Academic Purposes (EAP) should play an important role in English teaching for non English program, specifically in higher formal education. This is a descriptive research that used observation, questionaire and interview. The data analysis and interpretation indicates that, 1) Learners' proficiency in English writing for Academic Purposes in formal higher education is a must for use to enhance the learners' academic performance. It is important for the lecturer to provide the suitable learning material and learning technique based on the requirement; 2) Learners' English writing skill for academic purposes needs require ability in summarizing, paraphrasing, writing in academic genres like essays, reports and literature reviews, and writing in rhetorical-functional like explaining, defining and drawing conclusion.
\end{abstract}

Keywords: EAP, writing, needs, descriptive research

\section{A. INTRODUCTION}

\section{Background}

Nowdays, the concept of English for Academic Purposes (EAP) as a part of English for Specific purposes (ESP) have been the major driver for the changes in the English Language Teaching Program, specifically in formal higher education field. The goal of EAP is to help the learners to develop their study skills abilities that are required to be used in any formal higher education field. Study skills reflected by integrated skills between receptive and productive skills; listening to speaking and reading to writing. The lecturer must realize that non English Department learners should be supported the English skills that will help them to do any activities as learners in formal higher education. 
There are four skills that must be mastered by the English learners. Most of them thought that writing is the most difficult skill to be mastered. There are many components that must be mastered, started from vocabulary mastery until structure pattern. The difficulty is not only about mechanism aspects but also how to present our opinions, ideas and thinking about the subject. This skill has a relation with the learners' schemata. It will be easier to write if we know a lot; we can write if we like to read.

In this current formal higher education situation, specifically in non English Department, there is a requirement for the learners to use many English books related with their major. They are expected to read the English books and to know their comprehension, the lecturers will ask them to write by using their own words. By the latest semester they must write an English article concerning with their subject and for the learners that will prepare their thesis (skripsi), they must write the abstract in English.

The above description was not reflected in English teaching for non English Department learners. They tend to be taught the general English, focus on grammar, tenses and vocabulary mastery. Most of the learners do not know how to present their thinking, opinions and ideas writenly. They do not know what is the academic writing as required in formal higher education field. It can be sen by their performace in writing. Many non English Educational Department students having some difficulties to transfer their skills into English and to adjust them to a different academic environment. Many of them haven't practised study skills efficiently through the medium of English.

This study would benefit language lecturers in their attempt to improve teaching practices particulary in the development of teaching and learning process based on learners' needs, specifically on the development of students' writing skill. Finally this study could serve as a basis for other researches in the development of acceptable, useful substantial and appropriate teaching and learning process that would enhance learners' writing skills. 


\section{The Objective}

Based on the problem aboved, the objective of this study is to get the understanding about the learners' needs of English writing skill for academic purposes in formal higher education.

\section{Theoretical Framework}

Teaching English as foreign language must be based on the learners' needs. In the higher formal education field, learners are expected to use their English skills in doing any activities that will support the teaching and learning process, including the non English Department learners. As a part of English for Specific Purposes (ESP), English Academic Purposes (EAP) is concerned with those communication skills in English which are required for study purposes in formal education system. (Jordan, 1997:1). Dudley-Evans notes (2001, ix) that: "EAP often tends to be a practical affair, and these areas are typically understood in terms of local contexts and the needs of particular students". Based on the statement, we realize that English for Academic Purposes courses must focus on empowering students to develop and use skills which can facilitate them to be a part of learning process in an academic teaching and learning field.

Practically EAP is devided into English for General Academic Purposes (EGAP) and English for Specific Academic Purposes (ESAP). An awareness of the distinction between EGAP and ESAP is crucial to a full undertanding of EAP (Blue, 1988a). EGAP focus on teaching of the skills and language that are common to all disciplines; ESAP refers to the teaching of the features that distinguish one discipline from others. The basic requirement of English skills proficiency for non English learners is EGAP, that isolates the skills associated with study activities such as reading textbooks, or writing an essays.

According to Richards, Platt and Platt (1992) in Jordan (1997, 4) study skills defines as abilities, techniques, and startegies which are used when reading, writing or listening for study purposes. For example, study skills required by university students studying from English-language textbooks. 
Based on the statement, we realize that study skills covers receptive and productive skills, both listening and speaking or reading and writing. The receptive skills are seen as important inputs to the productive skills, with each receptive skills having its place with each productive skill, depending on the appropriate study situation or activity. Study skills is reserved for the more mechanical aspects of study that must be used by the non English Department learners.

English writing for academic purposes as a part of study skills is required to be mastered by the formal higher education students. Writing for academic purposes related with academic reading mastery. Students tend to deliver their comprehension of some subject writenly. Students on higher education level are expected to write on their own. It will occupies a large proportion of their studi time. It is supported by the statement from Kim and Kim (2005), "Writing is an important and, at the same time, demanding activity, particularly in a foreign language context in which learners are exposed to language just for few hours a week". Writing plays important role in academic lives and it is considered as the reliable source of self expression and understanding. For the academic success, good writing skills are essential that covers a mastery of proper spelling, grammar usage and a professional ways of imparting information.

Needs is an umbrella that will cover many aspects, specifically in learning and teaching process. Needs analysis refers to the techniques for collecting and assessing information relevant to course design: it is the means of establishing the how and what of a course. (Hyland, 2006: 73). It is quite important for the lecturers for doing need analysis before implementing the course. The result of it will be as a guidance to choose the appropriate material, method or technique in teaching and evaluation, so the goal of the learning process will be achieved easily. In doing need analysis, the lecturer must concern between the result of present situation analysis and target situation analysis. The gap between them will be as a corner stone to design a proper course. 
Need analysis is a key stage in EAP which is not separate with course design, materials selection, teaching and learning and evaluation. Need analysis is the process of establishing the what and how of a course. Robinson (1991:16) said that repeated needs analysis can be built into the formative evaluation process. By doing the need analysis we can improve the quality of teaching and learning process. We know the information about target situation analysis and objective needs by need analysis. We will get the information about learners' wants, means and subjective needs including present situation analysis, and learning needs. The result of them will be as a guidance in doing continuous improvement of teaching nad learning quality, specifically in English writing skill for Academic purposes in formal higher education field.

\section{METHODOLOGY}

This study aimed to get the understanding about the students' needs of English writing skill for academic purposes in formal higher education. This research is held at STKIP Kusuma Negara, Jakarta. Research methodology used a qualitative descriptive method as empirical and theoretical approaches. The data were collected through participants by using questionnaire, observation sheet and document study.

\section{B. RESULT AND DISCUSSION}

\section{Result}

The research result through observation, questionnaires and interviews show that Non English Educational Department students need help with both the language of academic disciplines and the specific study skills required for them during their course. It may involve English writing skill based on the context. Their proficiency in English writing for Academic Purposes in formal higher education is a must for use to enhance the academic performance. It is important for the lecturer to provide the suitable learning material and learning technique based on the requirement. 
Student' English writing skill for academic purposes needs require ability in the field of rhetorical functional which are including description, narrative, definition, and classification. Besides that, writing in academic genre must be required by them. They are expected to become familiar with and to produce: essays, reports, projects, literature reviews and research papers. Summarizing and paraphrasing are the important aspects of academic writing that must be mastered by non English learners.. It is important for the student to use the source texts as a key element of English writing for Academic purposes instruction. The connection between reading and writing is the important one, it will involve the knowledge of telling and trasforming or presenting. Knowing about genre is also a key element in all communication, specifically in the form of writing academic. The student should understand the context and the expectations of the discourse community as reader.

Student in higher education level requires ability writing in retoricalfunctional like explaining, defining and drawing conclusion. There is a demand to express their opinion writenly after comprehend a subject related with their major. Concerning with that the students' writing skills needs to be improved in organizing paragraph coherence and unity, how to organize the effective ideas and also grammar and vocabulary mastery.

\section{Discussion}

Based on the result, we can realize that study skills mastery is the important qualification that must be achieved by non English learners in doing the activity in teaching and learning process. As an approach, English Academic Purposes is a comprehensive way to fulfil learners' needs, including writing skill for academic purposes.

English writing skill for academic purposes focus on ability to know and produce writing in the field of rhetorical function in the academic styles, academic genres including summarising and paraphrasing. It is better for the lecturers to implement need analysis before starting the teaching process in 
order to know what is the most need that is required by the learners. The result of it will be as fundamental to design a comprehensive course.

\section{CONCLUSIONS AND SUGGESTIONS}

\section{Conclusions}

Based on the findings and discussion of research, it can be formulated some conclusions of English writing needs for academic purposes in formal higher education. First we have to realize that students in formal higher education require writing skill for academic purposes. In the beginning, as the instructor, lecturer should do need analysis to get the data what and how the suitable skill of English writing for Academic purposes must be conducted. As a part of ESP, we must realize that EAP is an approach not the product, so the whole thing related with EAP teaching and learning process must be related and focus to achieve students' needs.

Students' needs in formal higher education related with literacy, they are expected to get new knowledge by doing reading comprehension and writing. Students' writing is one of ways to know students' knowledge development. Related with that matter, they requires writing skills in the form of academic genre, like essay, report and literature review and also summarizing and paraphrasing. They are expected to be able in writing based on academic rhetorical-functional like explaining, defining and drawing conclusion.

\section{Suggestions}

Based on the conclusions aboved, there are some suggestions adviced,

1) Lecturers must know and understand the essence of English Academic Purposes to be implemented for non English learners.

2) It is important for the lecturers to do need analysis before started the course in order to get the information of learners's needs. The result of it must be a fundamental in make comprehensive course design. 


\section{BIBLIOGRAPHY}

Evans, Tony Dudley dan Maggie Jo St John. Developments in English for Specific Purposes. UK: Cambridge University Press, 1998.

Hyland, Ken. English for Academic Purposes. NY: Routledge, 2006.

Jordan, R.R. English for Academic Purposes. UK: Cambridge University Press, 1997.

Kim, Y., \& Kim, J. Teaching Korean university writing class: balancing the process and the genre approach. Asian EFL Journal, 7(2), 2005, 1-15.

Robinson, Pauline. ESP Today: a Practitioner's Guide. UK: Prentice Hall International, 1991. 